\title{
IMPLEMENTASI KEBIJAKAN E-GOVERNMENT MELALUI WEBSITE SUBANG.GO.ID DI DINAS KOMUNIKASI DAN INFORMATIKA KABUPATEN SUBANG
}

\author{
Regan Vaughan, R. Hari Busthomi, Anggi Andani Putri \\ Universitas Pasundan (UNPAS) Bandung Jawa Barat, Indonesia \\ Email: regan.vaughan@unpas.ac.id, hari.busthomi@unpas.ac.id, \\ andanianggi@gmail.com
}

\begin{abstract}
Technological developments require every aspect of life to adapt to the digital era, as well as the world of government. The birth of this digital era indeed provides solutions or strategies that have a very significant impact on improving the performance of public services that can support the creation of good governance. The challenges of the digital era in the midst of bureaucracy encourage expectations of openness, speed and accuracy of public services provided by the government. The Subang Regency Government innovates public services which are often known as EGovernment, one of the uses of E-Government through the subang.go.id website. The purpose of this research is to get an overview of the implementation of e-government policies through the subang.go.id website as well as the obstacles as well as the efforts made to overcome these obstacles. The research method used in this research is descriptive research method with a qualitative approach. Data collection techniques used in the form of observation, interviews, and documentation. The informants in this study were two people consisting of the Head of E-Government Services and the Head of Application Development. The results of this study indicate that the implementation of the E-Government Policy through the subang.go.id website is considered good. Based on the evaluation results of the Kemenpan-RB Subang Regency is already in the Good predicate with an Index Value of 3.01. It's just that in the implementation of E-Government through the website there are still things that need to be improved regarding the consistency or discipline of all parties and the addition of competent management staff. The conclusion from the results of this study in terms of the implementation of E-Government Policy through the subang.go.id website at the Communication and Information Office of Subang Regency is considered good.
\end{abstract}

Keywords: implementasiing; e-pemerintah; situs subang.go.id

\section{Abstrak}

Perkembangan teknologi yang menuntut setiap aspek kehidupan untuk beradaptasi ke era digital, begitupula dengan dunia pemerintahan. Lahirnya era digital ini memang benar memberikan solusi atau strategi yang berdampak sangat signifikan untuk meningkatkan kinerja pelayanan publik yang dapat menyokong terciptanya good governance. Tantangan era digital di tengah birokrasi mendorong harapan akan keterbukaan, kecepatan dan akurasi layanan publik yang diberikan pemerintah. Pemerintah Kabupaten Subang melakukan inovasi pelayanan publik

$\begin{array}{ll}\text { How to cite: } & \text { Vaughan, Regan, R Hari Busthomi, Anggi Andani Putri (2021), Implementasi Kebijakan E- } \\ & \text { Government Melalui Website Subang.go.id Di Dinas Komunikasi dan Informatika Kabupaten } \\ & \text { Subang. 3(6). https://doi.org/10.36418/syntax-idea.v3i6.1274 } \\ \text { E-ISSN: } & \text { 2684-883X } \\ \text { Published by: } & \text { Ridwan Institute }\end{array}$


yang sering dikenal dengan E-Government salah satu pemanfaatan E-Government ini melalui website subang.go.id. Tujuan dari penelitian ini adalah guna mendapatkan gambaran terkait Implementasi Kebijakan E-government melalui website subang.go.id serta hambatan juga upaya yang dilakukan untuk mengatasi hambatan itu. Metode penelitian yang digunakan dalam penelitian ini adalah metode penelitian deskriptif dengan pendekatan kualitatif. Teknik pengumpulan data yang digunakan berupa teknik observasi, wawancara, dan dokumentasi. Informan dalam penelitian ini sebanyak dua orang yang terdiri dari Kepala Bidang Layanan E-Government dan Kasi Pengembangan Aplikasi. Hasil dari penelitian ini menunjukkan bahwa implementasi Kebijakan E-Government melalui website subang.go.id dinilai telah baik. Berdasarkan hasil evaluasi Kemenpan-RB Kabupaten Subang sudah berada pada predikat Baik dengan Nilai Indeks 3,01. Hanya saja dalam pelaksanaan E-Government melalui website masih ada yang perlu ditingkatkan lagi terkait konsistensi atau kedisiplinan seluruh pihak serta penambahan staff pengelola yang kompeten.

Kata Kunci: implementasi kebijakan; e-government; website subang.go.id

\section{Pendahuluan}

Perkembangan teknologi informasi dan komunikasi yang pesat sebagai dampak dari globalisasi marak diperbincangkan. Istilah Revolusi Industri 4.0 hal ini menambah fokus kajian administrasi publik untuk menghadapi beragam tantangannya dan perlu bereformasi. Menurut (Pasolong, 2017) menyatakan bahwa administrasi publik adalah manajemen dan organisasi dari manusia-manusia dan peralatannya guna mencapai tujuan pemerintah. Tantangan tersebut termasuk dengan lahirnya era digital di tengah birokrasi sebagai suatu alat pendukung yang akan mendorong harapan akan keterbukaan, kecepatan dan akurasi layanan publik yang diberikan pemerintah.

Lahirnya era digital ini memang benar memberikan solusi atau strategi yang berdampak sangat signifikan untuk meningkatkan kinerja pelayanan publik yang dapat menyokong terciptanya good governance. Good governance diartikan sebagai kualitas hubungan yang dibangun oleh pemerintah kepada masyarakat yang dilayaninya (Rahmadana et al., 2020).

Menurut (Sedarmayanti, 2020) governance sendiri mencakup 3 (tiga) sektor yaitu state (Negara/Pemerintahan), private sectors (Sektor swasta/Dunia Usaha), dan society (masyarakat). Perkembangan good governance di Indonesia didorong oleh adanya dinamika yang menuntut perubahan, baik di lingkungan pemerintah, dunia usaha swasta maupun masyarakat. Good governance menurut United Nations Development Programme (UNDP) jika diinterpretasikan adalah satu bentuk hubungan kerjasama yang sinergis diantara Negara, Sektor Swasta dan masyarakat, dengan menerapkan prinsip-prinsip: partisipasi, supremasi hukum, transparansi, cepat tanggap, membangun konsesus, kesetaraan, efektif dan efisien, bertanggung jawab serta visi strategik.

Menurut LAN yang dikutip (Anggara, 2012) bahwa kebijakan sebagai ketentuanketentuan yang harus dijadikan pedoman, pegangan atau petunjuk bagi setiap usaha dan kegiatan aparatur pemerintah, sehingga tercapai kelancaran dan keterpaduan dalam mencapai tujuan. Berdasarkan pernyataan tersebut dapat disimpulkan bahwa Good 
governance merupaka suatu asas yang dapat dijadikan pedoman pada upaya untuk megutamakan kepentingan rakyat sehingga keterlibatan pemerintah sebagai pelayan publik juga diperlukan untuk lebih memahami apa yang menjadi harapan masyarakat yang dapat dituangkan dalam kebijakan-kebijakan pemerintah.

Keterlibatan stakeholder dari pemerintah ini yang diperlukan dalam penerapan konsep good governance yaitu keadilan, pemerataan, persamaan, efisiensi, transparansi, dan akuntabilitas informasi yang dapat dibangun pemerintah. Keterlibatan ini juga yang menjadikan masyarakat juga memiliki tanggungjawab yang sama besarnya dalam mengawasi pemerintahan dan menyalurkan aspirasinya pada pemerintah (Khamim, 2021).

Konsep birokrasi yang lahir dari era digital ini di kenal dengan E-Government. Salah satu tujuan implementasi E-Government tak lain adalah agar lembaga pemerintah mampu menyediakan pelayanan publik yang prima sehingga konsep good governance dapat diwujudkan secara optimal. Dalam kaitan ini dibutuhkan komitmen yang kuat dari pemerintah untuk merintis dan memulai hal yang baru dalam birokrasi. Pemanfaatan EGovernment bagi birokrasi diharapkan dapat menjadi alternatif bagi reformasi birokrasi menuju pelayanan prima. Tentu kesiapan sumber daya manusia, regulasi, anggaran dana, sarana dan prasarana adalah hal mutlak yang harus disiapkan pula dalam proses penyelenggaraannya (Napitupulu et al., 2020).

Pelayanan publik yang prima adalah memberikan berbagai pelayanan publik yang dibutuhkan oleh masyarakat, mulai dari pelayanan dalam bentuk regulasi ataupun pelayanan-pelayanan lain dalam rangka memenuhi kebutuhan masyarakat di dalam berbagai bidang seperti pendidikan, kesehatan, ekonomi, serta infrastruktur dan lain sebagainya (Hardiyansyah, 2018).

Globalisasi kini tidak terpisahkan dari masyarakat modern yang telah menuntutnya kepada kebutuhan yang lebih kompleks dan lebih besar terhadap pemerintah sebagai penyedia layanan. Harapan-harapan untuk lebih bersifat terbuka, lebih efektif dan efisien dalam melaksanakan tugas sebagai pelayan publik, dan juga memberikan kemudahan terhadap akses informasi khususnya informasi seputar kegiatan pemerintah yang melibatkan masyrakat, atau pemerintah dengan swasta, bahkan pemerintah dengan pemerintah.

Dengan keluarnya Instruksi Presiden RI (Undang-undang No 23 Tahun 2014) Government merupakan langkah serius Pemerintah Indonesia untuk memanfaatkan teknologi informasi dan komunikasi di dalam proses pemerintahan dan menciptakan masyarakat Indonesia yang berbasis informasi. Electronic government merupakan upaya muwujudkan pemerintahaan yang demokratis, akuntabel, transparan dan efisien, menjungjung tinggi superemasi hukum, dan membuka partisipasi masyarakat yang dapat menjamin kelancaran, keserasian dalam fungsi penyelenggaraan pemerintahan.

Sejalan dengan yang dikemukan oleh The World Bank dapat ditarik kesimpulan bahwa E-Government ialah sebagai upaya pemanfaatan informasi dan teknologi komunikasi untuk meningkatkan efesiensi dan efektivitas, transfaransi dan akuntabilitas pemerintah dalam memberikan pelayanan publik secara lebih baik. 
Untuk memberikan pelayanan publik yang lebih baik tentu dibutuhkan suatu teorobosan atau inovasi baru selaras dengan yang tencantum dalam UU No. 23 Tahun 2014 tentang Pemerintahan Daerah bab XXI bertajuk Inovasi Daerah pasal 386 hingga pasal 390 UU 23/2014, menjelaskan bahwa dalam rangka peningkatan kinerja penyelenggaraan Pemerintahan Daerah, Pemerintah Daerah dapat melakukan inovasi.

Inovasi sebagaimana dimaksud adalah semua bentuk pembaharuan dalam penyelenggaraan Pemerintahan Daerah. Dalam merumuskan kebijakan inovasi, Pemerintahan Daerah mengacu pada prinsip: peningkatan efisiensi; perbaikan efektivitas; perbaikan kualitas pelayanan; tidak ada konflik kepentingan; berorientasi kepada kepentingan umum; dilakukan secara terbuka; memenuhi nilai-nilai kepatutan; dan dapat dipertanggungjawabkan.

Kabupaten Subang sendiri kini inovasi tersebut berbentuk website Subang.go.id. Salah satu kegiatan yang dilakukan pemerintah kabupaten Subang dalam implementasi E-Government adalah pemanfaatan website. Hal tersebut tertuang dalam Peraturan Bupati No. 49 Tahun 2015 Bab 2 Pasal 3. Pendayagunaan website didalam lingkup pemerintahan pun tertuang didalam Peraturan Bupati Subang No. 50 Tahun 2015 sebagai penyampaian informasi serta media komunikasi dan aspirasi masyarakat.

\section{Metode Penelitian}

Pendekatan yang digunakan dalam penelitian kali ini adalah Penelitian kualitatif dengan pendekatan fenomenologi. Penelitian kualitatif mengkaji perspektif partisipan dengan strategi-strategi yang bersifat interaktif dan fleksibel. Penelitian kualitatif ditujukan untuk memahami fenomena-fenomena sosial dari sudut pandang partisipan (Sugiyono, 2012).

Data primer adalah pengambilan data dengan instrumen pengamatan, wawancara, catatan lapangan dan penggunaan dokumen. Sumber data primer merupakan data yang diperoleh langsung dengan teknik wawancara informan atau sumber langsung. Sumber primer adalah sumber data yang langsung memberikan data kepada pengumpul data (Sugiyono, 2012). Adapun dalam penelitian ini sumber data primer meliputi; Kepala Bidang Layanan E-Government, Kepala Seksi Pengembangan Aplikasi.

Sumber data sekunder adalah data yang digunakan untuk mendukung data primer yaitu melalui studi kepustakaan, dokumentasi, buku, majalah, koran, arsip tertulis yang berhubungan dengan obyek yang akan diteliti pada penelitian ini (Barrir Ibrahim, 2019). Adapun dalam penelitian ini sumber data sekunder meliputi; Situs website subang.go.id, Buku pedoman website, Data Update Database Tahun 2016-2020 dan Renja perubahan 2021.

Teknik pengumpulan data digunakan untuk mengumpulkan data sesuai tata cara penelitian sehingga diperoleh data yang dibutuhkan. Menurut (Sugiyono, 2012), teknik pengumpulan data merupakan langkah yang paling strategis dalam penelitian, karena tujuan utama dari penelitian adalah mengumpulkan data. Teknik pengumpulan data dalam penelitian menggunakan teknik observasi, wawancara, dan dokumentasi. 


\section{Hasil dan Pembahasan}

Adanya E-Government ini juga merupakan bentuk fokus terbaru dari administrasi publik menjadi suatu sarana penunjang terciptanya akuntabilitas dan transparansi dari Pemerintah Kabupaten Subang kepada Masyakarat Subang (Safitri, 2019).

Menjalankan tugasnya sebagai pengelola E-Government di ruang lingkup Pemerintah Kabupaten Subang Dinas Komunikasi dan Informatika berpedoman kepada salah satu diantaranya adalah (Peraturan Bupati Subang Nomor 49 Tahun 2015) tentang Implementasi E-Government di lingkungan Pemerintah Kab. Subang, Instruksi Presiden No 3 Tahun 2003 tentang kebijakan dan strategi nasional pengembangan E-Government dan (Peraturan Presiden No. 95 tahun 2018) tentang Sistem Pemerintahan Berbasis Elektronik. Menurut (Winarno, 2012) bahwa implementasi adalah apa yang terjadi setelah undang-undang ditetapkan yang memberikan otoritas program, kebijakan, keuntungan atau suatu jenis keluaran yang nyata. Pernyataan tersebut dapat mempertegas bahwa ketika regulasi tentang E-Government ini telah ditetapkan selanjutnya adalah bagaimana para stakeholders yang terkait melaksanakannya guna mencapai tujuan yang telah ada.

Berdasarkan (Peraturan Presiden No. 95 tahun 2018) yang selanjutnya disingkat SPBE ini merupakan suatu aturan yang mengatur tentang pelaksanaan kegiatan pemerintahan sebagai pelayan publik dengan memanfaatkan teknologi sehingga dapat menunjang kegiatan pemerintah yang lebih efektif, efisien, cepat, mudah, transparan, dan akuntabel.

Memastikan kemajuan serta sebagai bahan untuk perbaikan guna peningkatan kualitas pelayanan selanjutnya, maka dibutuhkan suatu tindakan evaluasi sehingga hasil dari evaluasi ini akan menunjukkan sejauh mana tingkat kematangan suatu daerah, instansi, atau lembaga dalam proses implementasi E-Government atau Pemerintahan Berbasis Elektronik.

Pada tahun 2019, Kemenpan-RB telah melakukan evaluasi pada pelaksanaan SPBE di setiap daerah, instansi ataupun lembaga. Kegiatan E-Government di ruang lingkup pemerintahan Kabupaten Subang sendiri berdasarkan hasil evaluasi sudah berada pada predikat Baik dengan Nilai Indeks 3,01. Berdasarkan hasil evaluasi nilai indeks oleh KEMENPAN-RB yang diraih oleh Pemerintah Kabupaten Subang menjadi acuan atau sasaran untuk perbaikan dan pengembangan E-Government di Kabupaten Subang kedepannya, sejalan dengan yang dikemukakan oleh (Silalahi, 2016) tentang salah satu dimensi administrasi yaitu "Adanya sasaran yang digunakan oleh sekelompok atau lembaga dalam melaksanakan tujuan yang hendak dicapai." Karena E-Government ini juga merupakan bagian dari kegiatan administrasi terbarukan yang berbasis online. 

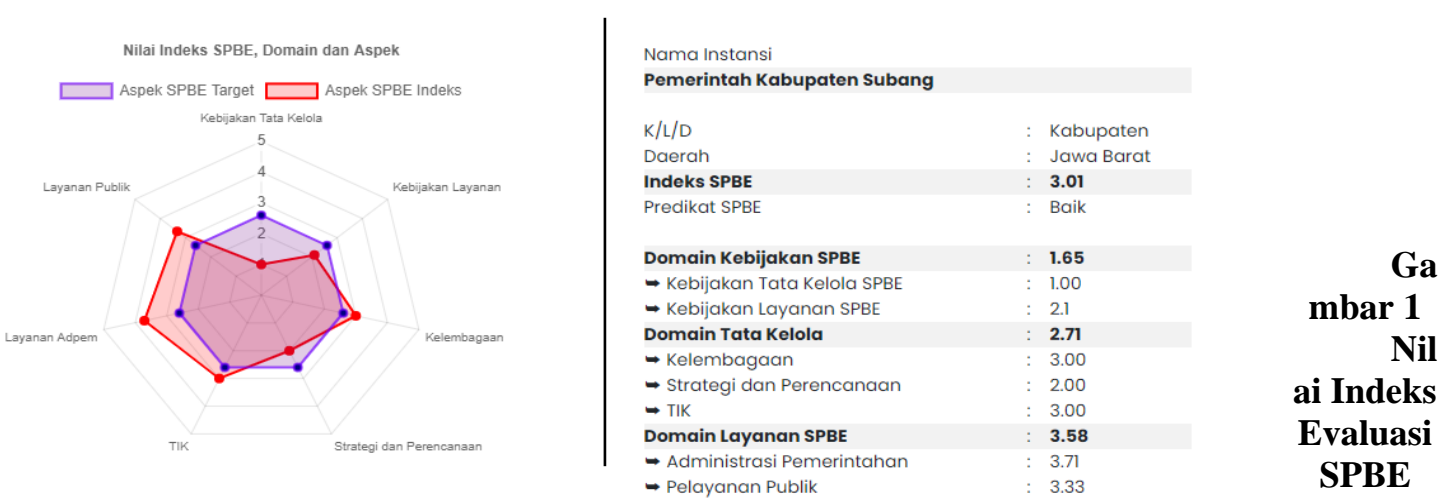

mber: Website Kemenpan-RB RI

Su

Maka, hasil dari pada penelitian kali ini menunjukkan bahwa implementasi EGovernment di Kabupaten Subang secara keseluruhan telah dilaksanakan sudah baik. Kini yang menjadi fokus daripada penelitian ini adalah bagaimana dengan Implementasi E-Government melalui Website Subang.go.id di Dinas Komunikasi dan Informatika Kabupaten Subang. Melihat bahwa Website ini menjadi wajah terdepan bagi pelaksanaan E-Government di Kabupaten Subang.

\section{A. Implementasi E-Government melalui website subang.go.id di Dinas Komunikasi dan Informatika Kabupaten Subang.}

Mengacu indikator kualitas pelayanan menurut (Agustino, 2016):

1. Komunikasi

Komunikasi dalam Implementasi Kebijakan E-Government melalui website subang.go.id itu sudah cukup baik, namun poin konsistensi masih harus ditingkatkan dan perlu jadi perhatian lebih sehingga tingkat koordinasi antar berbagai pihak bisa lebih disiplin. Selain itu, harus pula ada koordinasi yang sinergis antara beberapa pihak sehingga aspek kebermanfaatan dari EGovernment ini bisa benar terasa oleh seluruh elemen. Keberhasilan suatu kebijakan yang dibuat oleh pemerintah tidak hanya dilakukan oleh satu pihak saja. Tetapi, kerjasama antara pemerintah, swasta, dan masyarakat juga sangat penting untuk menunjang keberhasilan suatu kebijakan.

2. Sumber Daya

Aspek sumber daya ini proses Implementasi Kebijakan E-Government melalui website subang.go.id sudah cukup baik namun hal krusial yang harus ditingkatkan adalah terkait penambahan staff yang berkualitas dan berkompeten pada bidang TIK dan fasih dalam pengelolaan website yang tentu juga diimbangi dengan anggaran yang tersedia guna kebutuhan pemberian upah pegawai.

3. Disposisi (Sikap)

Diterapkannya E-Government ini dapat tercipta pelayanan publik yang efektif, efisien, akuntabel, transaparan juga cepat. Apabila sikap daripada implementator tidak menunjukkan atau tidak mengarah pada sikap seorang 
pelayan publik bisa saja kehadiran E-Government ini malah menjadi boomerang untuk pemerintahan dan masyarakat. Kehadiran website subang.go.id ini dinilai telah baik terkhusus dalam situasi pandemi yang bisa menjadi garda terdepan pusat informasi terkait Pemerintahan Kabupaten Subang.

4. Struktur Birokrasi

Dengan mengacu pada Perbup No. 49 Tahun 2015 pedoman-pedoman tugas pokok dan fungsinya telah disusun secara jelas pada peraturan-peraturan yang berlaku tersebut sehingga Dinas Komunikasi dan Informatika Kabupaten Subang selaku stakeholders E-Government di Lingkungan Pemerintah Kabupaten Subang bertanggung jawab penuh terhadap perjalanan dan pemanfaatan sistem EGovernment. Bidang Layanan E-Government ini sendiri juga selalu melakukan kontrol serta pengawasan terhadap implementasi kebijakan ini agar berjalan sebagaimana mestinya sehingga dapat terwujud tujuan dari diadakannya EGovernment.

\section{B. Hambatan dalam penerapan E-Government melalui website subang.go.id}

Hambatan dalam implementasi E-Government melalui website subang.go.id di Dinas Komunikasi dan Informatika Kabupaten Subang apabila mengacu kepada indikator yang dikemukakan oleh (Agustino, 2016) terdapat hambatan dalam aspek Komunikasi yaitu di poin Konsistensi dan Sumber Daya yaitu di poin Staff.

1. Komunikasi

Dilihat dari poin Konsistensi. Mengingat pada Pasal 20 BAB VIII Perbup No. 49 Tahun 2015 telah disebutkan bahwa "setiap Organisasi Perangkat Daerah (OPD) yang memiliki database dan informasi pada aplikasi/website Pemerintah Kabupaten Subang kepada Dinas Komunikasi dan Informatika”. Walaupun telah ada regulasi yang mengatur hal ini justru menjadi kendala, karena pada kenyataannya masih banyak OPD yang tidak melakukan update database dilihat pada tahun ini persentase update database menurun dari tahun sebelumnya. Salah satu faktor utama terjadinya penurunan diakibatkan adanya pandemi covid-19 sehingga mengalihkan fokus setiap OPD terhadap isu-isu kesehatan. Jadi, tingkat konsistensi atau kedisiplinan dari OPD dalam melakukan update masih sangat rendah. Lalu, tingkat koordinasi dari Diskominfo sendiri terhadap BUMD. Contohnya dengan PDAM, sebenarnya telah disediakan fitur Cek Rekening PDAM tetapi fitur tersebut tidak dapat dipergunaka dan tidak dapat diakses. 
Update Database Website

\begin{tabular}{ccccccc}
\hline $\begin{array}{c}\text { Jumlah } \\
\begin{array}{c}\text { Keseluruhan } \\
\text { Website }\end{array}\end{array}$ & \multicolumn{3}{c}{$\begin{array}{c}\text { OPD yang Update } \\
\text { Database }\end{array}$} & \multicolumn{2}{c}{$\begin{array}{c}\text { OPD yang Tidak Update } \\
\text { Database }\end{array}$} \\
\hline \multirow{3}{*}{31} & $2017-$ & $2018-$ & $2019-$ & $2017-$ & $2018-$ & $2019-$ \\
& 2018 & 2019 & 2020 & 2018 & 2019 & 2020 \\
\cline { 2 - 7 } & $87,5 \%$ & $83 \%$ & $74 \%$ & $12,5 \%$ & $17 \%$ & $26 \%$ \\
\hline
\end{tabular}

Komunikasi dan Informatika



Tampilan Fitur Cek Rekening PDAM

Gambar 2

Sumber: Dinas Komunikasi dan Informatika

2. Sumber Daya

Melihat dari poin staff, Kegagalan yang sering terjadi dalam implementasi kebijakan salah satunya disebabkan oleh karena staff yang tidak mencukupi, memadai, ataupun tidak kompeten di bidangnya. Penambahan jumlah staff atau implementator saja tidak mencukupi, tetapi diperlukan pula kecukupan staff dengan keahlian serta kemampuan yang diperlukan. Begitu pula dengan yang terjadi di Dinas Komunikasi dan Informatika secara kualitas staff yang ada telah baik dan kompeten pada bidangnya. Tetapi, dari segi kuantitas masih belum mencukupi masih perlu penambahan personil staff pengelola website. Hal ini juga harus diperhatikan oleh Dinas Komunikasi dan Informatika Kabupaten Subang agar bisa mengambil sikap untuk mensiasati permasalahan tersebut. Terkait penambahan staff ini pun nantinya akan berdampak kepada pengeluaran anggaran untuk kegunaan pemberian upah, maka alternatif solusi harus matang dipertimbangkan agar penyelesaian masalah bisa teratasi tanpa memberikan dampak buruk lain terhadap aspek lain.

\section{Upaya dalam mengatasi hambatan dalam penerapan E-Government melalui website subang.go.id}

Dinas Komunikasi dan Informatika dalam mengatasi hambatan kini lebih kepada memanfaatkan sumber daya yang ada dengan semaksimal mungkin ditengah pandemi covid-19 yang mengharuskan berbagai kegiatan beralih menjadi berbasis 
daring. Upaya yang dilakukan adalah dengan meningkatkan intensitas komunikasi melalui pengawasan dan evaluasi dalam rapat walaupun secara virtual. Lalu, memaksimalkan pendidikan dan pelatihan terhadap ASN setempat, sehingga permasalahan kekurangan staff ini dapat sedikit teratasi dikarenakan adanya peningkatan soft skill staff yang ada agar bisa bekerja lebih maksimal dan efisien.

\section{Kesimpulan}

Berdasarkan hasil penelitian dilapangan dapat disimpulkan yaitu; Dalam hal implementasi Kebijakan E-Government melalui website subang.go.id di Dinas Komunikasi dan Informatika Kabupaten Subang dinilai telah baik. Pada penilaian kegiatan E-Government di ruang lingkup pemerintahan Kabupaten Subang sendiri berdasarkan hasil evaluasi Kemenpan-RB sudah berada pada predikat Baik dengan Nilai Indeks 3,01. Hal ini menunjukkan bahwa dalam ruang lingkup Pemerintahan Kabupaten Subang telah berupaya untuk memaksimalkan implementasi E-Government. Istilah EGovernment di Indonesia kini juga dikenal dengan istilah SPBE (Sistem Pemerintahan Berbasis Elektronik). (1) Hambatan yang terjadi pada impelementasi E-Government melalui website subang.go.id dinilai tidak ada hambatan yang signifikan, permasalahan terletak pada poin konsistensi yang sehingga dapat menghambat ketepatan waktu dalam pemenuhan kebutuhan implementasi seperti kebutuhan data yang melebihi batas waktu. Hal ini juga diakibatkan oleh kurangnya staff sumber daya manusia yang pengelola sehingga fungsi controlling kurang berjalan maksimal. (2.) Upaya yang dilakukan oleh Dinas Komunikasi dan Informatika Kabupaten Subang dalam mengatasi hambatan penerapan E-Government melalui website subang.go.id memanfaatkan sumber daya yang ada dengan semaksimal mungkin ditengah pandemi covid-19 upaya yang dilakukan adalah meningkatkan intensitas komunikasi melalui pengawasan dan evaluasi dalam rapat walaupun secara virtual. Lalu, memaksimalkan pendidikan dan pelatihan terhadap ASN setempat, sehingga permasalahan kekurangan staff ini dapat sedikit teratasi dikarenakan adanya peningkatan soft skill staff yang ada agar bisa bekerja lebih maksimal dan efisien. 
Regan Vaughan, R. Hari Busthomi, Anggi Andani Putri

\section{BIBLIOGRAFI}

Agustino, Leo. (2016). Dasar-dasar kebijakan publik (Edisi Revisi). Bandung: Alfabeta.Google Scholar

Anggara, Sahya. (2012). Ilmu Administrasi Negara: Kajian Konsep, Teori, dan Fakta Dalam Upaya Menciptakan Good Governance (Vol. 1). CV Pustaka Setia. Google Scholar

Barrir Ibrahim, Bharata. (2019). Peranan Kh Abdul Wahid Hasjim Dalam Perkembangan Partai Masyumi Tahun 1943-1953. Universitas Siliwangi. Google Scholar

Hardiyansyah, Hardiyansyah. (2018). Kualitas Pelayanan Publik: Konsep, Dimensi, Indikator dan Implementasinya. Gava Media. Google Scholar

Khamim, Mohamad. (2021). Peran DPRD dalam Mewujudkan Good Governance di Daerah. Penerbit NEM. Google Scholar

Napitupulu, Darmawan, Lubis, Muhammad Ridwan, Revida, Erika, Putra, Surya Hendra, Saputra, Syifa, Negara, Edi Surya, \& Simarmata, Janner. (2020). EGovernment: Implementasi, Strategi dan Inovasi. Yayasan Kita Menulis. Google Scholar

Pasolong, Harbani. (2017). Teori Administrasi Publik. Bandung: Alfabeta.

Peraturan Bupati Subang Nomor 49 Tahun 2015. Implementasi E-Government di Lingkungan Pemerintah Kabupaten Subang.

Peraturan Presiden No. 95 tahun 2018. (2018). Sistem Pemerintahan Berbasis Elektronik.

Rahmadana, Muhammad Fitri, Mawati, Arin Tentrem, Siagian, Nurhayati, Peranginangin, Mori Agustina, Refelino, John, Tojiri, Moch Yusuf, Siagian, Valentine, Nugraha, Nur Arif, Manullang, Sardjana Orba, \& Silalahi, Marto. (2020). Pelayanan Publik. Yayasan Kita Menulis. Google Scholar

Safitri, Laras Sirly. (2019). Pemanfaatan Teknologi Informasi dan Komunikasi Dalam Mengakses Kredit Bagi Petani. The World of Business Administration Journal, 125-142. Google Scholar

Sedarmayanti, Sedarmayanti. (2020). Membangun sistem Manajemen Kinerja Guna Meningkatkan Produktivitas Menuju Good Governance. Jurnal Wacana Kinerja: Kajian Praktis-Akademis Kinerja Dan Administrasi Pelayanan Publik, 7(2), 1-16. Google Scholar

Sugiyono. (2012). Metode Penelitian Kuantitatif Kualitatif dan R\&D. Bandung: Alfabeta. Google Scholar 
Undang-undang No 23 Tahun 2014. Pemerintahan Daerah bab XXI bertajuk Inovasi Daerah pasal 386 hingga pasal 390 UU 23/2014. Undang-Undang No 23 Tahun 2014.

Winarno, Budi. (2012). Kebijakan publik: teori, proses, dan studi kasus: edisi dan revisi terbaru. Center for Academic Publishing Service. Google Scholar

\section{Copyright holder :}

Regan Vaughan, R Hari Busthomi dan Anggi Andani Putri (2021)

\section{First publication right :}

Jurnal Syntax Idea

This article is licensed under:

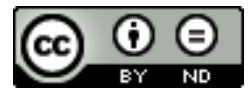

